\title{
The Myth About Heracles \\ in Literary Interpretation of P. Hacks (Based on the Play "Omphale")
}

\author{
Tatiana S. Nipa and Vladislav E. Biktimirov* \\ Siberian Federal University \\ 79 Svobodny, Krasnoyarsk, 660041, Russia
}

Received 10.01.2017, received in revised form 18.12.2017, accepted 09.01.2018

The paper explores the literary reception of classical story of Heracles in the play "Omphale" by Peter Hacks. The usage of ancient Greek mythology stories, images and motives, their interpretation is an integral part of world literature's artistic practice, in particular, German literature. It is in German culture where a strong national tradition of artistic interpretation of antiquity was formed. Peter Hacks, who created a number of literary adaptations of famous myths ("Die schöne Helena", "Amphitryon", "Orpheus in der Unterwelt"), evolved in line with this tradition. Analysis of the play, which includes historical, literary, receptive and comparative approaches, allows us to study the functioning of reception mechanism and the adaptation of antique plays in modern times, as well as the peculiarity of German playwright's mythopoetry.

Keywords: P. Hacks, Hercules, Omphale, German literature, reception, myth, interpretation.

DOI: $10.17516 / 1997-1370-0212$.

Research area: philology.

\section{Introduction}

One of the main tendencies in $20^{\text {th }}$ century literature is rethinking of the antique legacy, in particular stories of the antique mythology. Writers of various aesthetic and political views, and from different literature areas, such as realism and modernism, resorted to mythologization. While creating works on a mythological material, the authors, usually, modernize ancient stories, fill them with new philosophical and ethical ideas, withdraw archaisms and complicated plot lines, which are difficult for a modern reader, add modern life's details etc.
As in antiquity, as today, among the big amount of character from the ancient Greek mythology, Heracles is of particular interest. The image of hero-demigod became a source of inspiration for the artists, sculptors, composers and writers; an object of scientific research for the historians, philosophers, philologists and cultural specialists. The image of Heracles had different artistic presentations back in the antiquity. For example, the translator of Euripides' tragedies, Innokenty F. Annensky, stated that Heracles appears in various capacities: as a "bonded laborer", as a "glorious winner", and as

(C) Siberian Federal University. All rights reserved

* Corresponding author E-mail address: nipat@mail.ru; v.e.biktimirov@yandex.ru 
a "hero" (Annensky, 1906: 402; quoted through Golosovker, 1987: 107). Such figure is capable of impossible tasks and solving mysteries. But at the same time we know the humorous image of Heracles from Aristophanes' comedies ("The Frogs", "Wealth"), Euripides' satiric dramas ("Alcestis", "Busiris") where he appears as an infamous glutton-hero, trickster and debauche. Besides, Maria E. Grabar-Passek noted that in some antique literary works Heracles does not strive towards happiness, but towards prowess. Words of cynic sage Dio Chrysostom about Diogenes are cited by researcher as an example: here Heracles is "tireless pedestrian, modest regarding all material benefits, barefooted, almost naked, armed with bow and bludgeon $<\ldots>$ the best model for courage" (GrabarPassek, 1966: 135).

Subsequent usage of Heracles' image is mostly connected with the interest of the writers towards his origin story, according to which he was born to mortal Alcmene and Zeus the Thunderer (Jean Rotrou "Les Deux Sosies" (1638), Jean-Baptiste Molière "Amphitryon" (1668), John Dryden “Amphitryon” (1690), Heinrich von Kleist "Amphitryon" (1807), Jean Giraudoux “Amphitryon 38” (1929), Georg Kaiser "Zweimal Amphitryon" (1944)), and towards different passages of his labours (Jean Rotrou "Hercule mourant" (1632), Jean-François Marmontel "Hercule mourant" (1761), Friedrich Dürrenmatt "Herkules und der Augiasstall" (1954), Frank Wedekind "Herakles" (1916-1917), Heiner Müller "Herakles 5" (1966), Henry Lion Oldie "A Hero Must Be Alone" (1996), "Odysseus Son of Laertes" (2000-2001)).

German playwright Peter Hacks created two plays about life of Heracles. His dramas "Amphitryon" (1967) and "Omphale" (1970) "are peculiar diptych" (Vengerova, 1979: 468). Not only Heracles, but also the interpretation of main issues (love, commitment to ideals, the destiny of a man in this world, society and etc.) connect these two works. Below we examine the features of antique myth's perception and interpretation in Peter Hacks' comedy “Omphale”.

\section{Theoretical framework}

The concept of literary reception is an important part of a dialogue within literature. Ideologists of comparative literature were the first ones in Slavic studies to address the problem of influence and comprehension of culture, literature and history codes (Alexander N. Veselovsky, Viktor M. Zhirmunsky, Dionis Durishin). In their works they studied similar motives, stories and images. It allowed them to draw conclusions about specific national, historical and individual features of different writers' works and about different forms of connections within literature. Researches did not use the term "reception", however, their ideas and study methods of literary texts of different cultures, of different branches of aesthetics and of different epochs in many respects anticipated the reader-response criticism.

In the middle of $20^{\text {th }}$ century the Constance School of Reader-Response criticism was formed. Its ideologists Hans-Robert Jauss and Wolfgang Iser developed new theories which explain the features of the reader-text's relationship. These studies not only describe how text enters certain literature range, but also define a role of a reader as a critic and as an interpreter. Russian literary researches acknowledged importance of Constance School in development of comparative literature. According to Marina V. Tsvetkova, "by focusing on unique features of each single act of perception, the school of reader reception makes it difficult to classify reception and breaks the ideas of dialogic interaction between both active text and reader. That is why theories of Constance School seem to be more efficient for Comparative Studies" (Tsvetkova, 2010: 9). 
Combination of comparative analysis and theories of Reader-Response criticism contributes to in-depth studies of literary text and not only in terms of its perception's history but in its understanding by different cultures".

\section{The reception of myth in Peter Hacks' play "Omphale"}

Unlike two other "antique dramas" of Peter Hacks, "Omphale" comedy ("Omphale", 1970) is an original story. According to Tatyana A. Sharypina, "not just dramatical piece as such but separate motives filled with burning social issues $\langle\ldots\rangle$ or different characters, episodes are used for interpretation" (Sharypina, 2001: 117). The episode according to which Heracles had to serve queen Omphale for his involuntary crimes (killing of Iphitus, son of Eurytus) underlies the play. In the antique literature it was adapted by Ovid in collection of epistolary poems "Heroides". One extract from IX Letter "Deianira to Hercules" describes Hercules being a slave to Omphale. Richard Graves, a prominent researcher of ancient Greek mythology, noted that "classical writers made Heracles's servitude to Omphale an allegory of how easily a strong man becomes enslaved by a lecherous and ambitious woman" (Graves, 2005: 699). According to the myth, queen Omphale wore the skin of the Nemean Lion, defeated by Heracles, and carried Heracles' olive-wood club whereas valiant hero had to wear women's clothing, apply cosmetics and spin wool. Peter Hacks neglects myth rules and makes disguise of Heracles and Omphale their informed choice. At the same time, he develops Ovid's connotations, according to which being a servant at Omphale's disposal is not atonement for Heracles, but a love adventure. According to Dieter Kraft, such "role reversal" is "not a joke" (Kraft, 2010: 162). In this transformation playwright sees a starting point for raising gender issues which were significant in $20^{\text {th }}$ century. For
Heracles the aim of such a carnival disguise is to satisfy his own desires and also to understand his beloved woman (in Omphale's case - her beloved man).

As it is known, while serving to queen Omphale, Heracles carried out a number of feats which are equally important to ten famous Labours: he captured the Cercopes, shot dead a gigantic serpent beside the river Sagaris, saved Daphnis and his beloved Pimplea from Lityerses. However, Hacks only resorted to the latter, the least known to modern reader, because it enables raising important issues for the playwright.

Self-determination, searching for a higher purpose and ideals are inextricably linked to the image of demigod Heracles in the play of the German playwright. Hacks' Heracles is not a thoughtless character, but a warrior tired of numerous battles and labours, reflecting upon the meaning of life and trying to understand himself:

Ich will mich ja verlieren! Nein, mit jedem

Erlegten Ungeheuer werd ich immer

Deutlicher ich. Mit jedem Keulenschlag

Erschlag ich eine Möglichkeit in mir.

Ich üb mich und verkümmre an der Übung (Hacks, 1972: 385).

He disguises himself in Omphale's clothes, applies rouge, perfumes himself with lavender, embroiders, and weeps. He suffers from a mental crisis, loss of ethical ideals and guiding lines. By creating a psychological profile of Heracles, Hacks skillfully blends together comical and tragical. On the one hand, Heracles laments meaningless battles, narrowness and poverty of people's minds, but on the other hand he does typical women's things: he uses lipstick, spins, asks Malis to sweep his hair. However, when the dangerous horrible monster Lityerses, which causes troubles to Omphale's subordinates, appeared, Heracles stopped funny game and returned to his familiar role as a warrior, defender and hero. The necessity of being a mother, the 
greatest function ever to be given to a woman, makes Omphale return to a familiar social role:

Nicht die du jüngst verließest, triffst du noch.

Du findest Mutter mich und aus der Freiheit, Dem vorgegeben Weibsein zu entrinnen,

In meinen Leib, durch Schmerz, zurückgeworfen (Hacks, 1972: 411).

The issues of personal identity, and relationship between man and society obtained a contemporary perspective:

Die Knüppel ists, der dich zum Mann macht, wie

Der Rocken mich zum Weib. Undgründlich schließt

Die Welt, meist ja drum richtig, übrigens (Hacks, 1972: 406).

The specificity of this issue interpretation is that the real titanic greatness lies not in numerous victories and triumphs but in neglecting the superficial attributes of heroism, glory and courage. Hack's character does not neglect the society itself but its conventions; not people but their narrow-mindedness; not enemies but their meanness.

Hack's queen of Lydia is not like other female characters from his "antique dramas". In contrast to Helena of Troy and Eurydice, Omphale does not seek for pleasures or love affairs with other men but dearly she shares her dreams and ideals with her beloved man. In this perspective the character that resembles Omphale in many ways is Alcmene from Hack's "Amphitryon" because both their images were influenced by the feminism of $20^{\text {th }}$ century. Omphale is not only Heracles' beloved woman but a self-sufficient woman with strength of character. She rejects an imposed traditional role of victim and slave wife who has to live in her husband's shadow. Omphale declaims her moral freedom and right to express her own ideas and to do different things. No social or gender prejudices restrict this right:
Ihr schwachen Arme, bang bewegtes Herz, Ihr fügt, ich weiß es, seiner Kraft nichts zu

Und nehmt dem Feind nichts von der seinigen.

Doch das sind Gründe $<\ldots>$

Zur banden Stätte flieg ich seines Ringens,

Sein Schicksal teilend, sei es, wie es sei (Hacks, 1972: 396).

It is indicative that Peter Hacks named his play after Heracles' beloved woman for that she turns to be a "neural stimulus" that induced Zeus' son to set out on a search for lost happiness and that made him reinterpret his system of values and moral ideas. Omphale turns to be a solid person whose love arouses Heracles' courage, boldness, will to victory and thus determines his status in society.

Peter Hacks was the first one in literature to pay close attention to relationship between two brothers - Heracles and Iphikles. His aim was to emphasize main character's merits by contrast. The writer focuses on literary study of character's personalities and tries to give reasons for their behavior in terms of psychology. For example, the image of Heracles' uterine brother Iphicles acquires new details. According to author, Heracles' success and glory, with which he was given by birthright and, subsequently, for his labours, sow the seeds of discord in Iphikle's heart. Iphikle is an antipode of Heracles: he is a coward, liar and envious man who claims Heracles' success as his own. Antithesis of two brothers uncovers their best and worst features:

Der Gerechtigkeitwegen, es kränkt mich, wenn alle Welt tut, als ob Alkmene nur einen Sohn hätte und nicht, wie es doch der Fall ist, zwei. Ich will nicht jegliches Verdienst für mich haben; du könntest geziemenderweise meinen Halbbruder Herakles mit erwähnen (Hacks, 1972: 369).

The researchers of Peter Hacks' works consider that the image of Lityerses is presented 
as an absolute essence of evil from $20^{\text {th }}$ century fascism. In contrast to his mythological prototype, Peter Hacks' Lityerses is a monster who looks like a dragon with anthropomorphous features. He ravages Omphale's kingdom and kidnaps Daphnis' beloved Pimplea, but his real significance manifests itself in equation to philosophy of totalitarianism. Not coincidently German researcher Peter Schütze stated that Lityerses is a $20^{\text {th }}$ century dictator, similar to Hitler, who rules "violently and destroys old order" (Schütze, 1976: 171). Lityerses destroys every beautiful and living thing, defiles human fates. As a result, Alkaios becomes a traitor and Iphikles is ready to commit heinous murder. Only a victory over an overwhelming evil can bring peace, harmony and prosperity to Hack's characters and to all mankind as well.

As for poetic manner of Hack's comedy, we should note that it is written in the tradition of classical drama: unities of action, time and place are respected; the characters are gods and heroes, and they are either positive, or negative. With respect to the tradition of the antique theatre, Peter Hacks also uses masks which help Heracles become Omphale and Omphale become Heracles, what makes all other characters confused.

The final monologue of Heracles adds philosophical sense into comedy. It declares strength and glory of humanism. Having defeated his enemy, Heracles plunges his weapon into the ground and turns into the olive tree, the symbol of peace, rebirth and freedom. In his monologue Heracles compares a growing tree with a man in a process of his personality development:

So auch des Menschen Umweg. Von Bedürfnis

Aus unbescholtner Einfalt abgerissen,

$\mathrm{Mu} ß$ er $\mathrm{zu}$ schlechten Zwecken sich verkleinern,

Bis einst, nach aller Übel Unterricht,
Dem bös und fruchtbarn Teil der reif und edle

In ihm gemeinte Baum entwächst und wieder

Er wird, was er, bevor ers nicht war, war (Hacks, 1972: 412).

Hack's desire to humanize antique myths correlates closely to philosophy of Thomas Mann. In his work "Joseph and his brother" Thomas Mann dwells upon his attempt "to balance and reconcile myth and history, to identify a role of myth in the organization of historical experience, to remain faithful to traditions and, at the same time, to pave the way for the future". Being an opponent of fascism, Thomas Mann fills myth with humanism ideas, alleviates tragic episodes, and rejects fascist interpretation of myth: "Myth was rescued from fascism, now, down to the smallest cells of language, it is pervaded with humanism's ideas, and if our descendants will find something significant in this novel then it will be the humanization of myth" (Mann, 1960: 178). Hacks' image of growing tree embodies the aspiration of mankind towards brighter future that is quite typical for $20^{\text {th }}$ century rich with tragedies and social cataclysms.

\section{Conclusion}

Thus, the analysis of antique myth's interpretation in Peter Hacks' comedy "Omphale" demonstrates how one of the two mechanisms by which reception works functions: it recreates, which means projection of personal world view on other works; it creates new works by using classical legacy of antiquity. Peter Hacks modernizes myth not by using anachronisms but by putting urgent modern issues, ideas and images into literary work. Hacks' characters from Greek mythology are given with mind and mentality of modern man because their behavior does not comply with antique times. In this vein Heracles is a man that suffers from internal contradictions; 
Omphale is a freethinking woman; and Lityerses is an embodiment of Nazism's ideology. Thus, being filled with modern issues, the myth in
Hacks' interpretation loses its connection with the historical period during which it was created, and, as a result, demonstrates its timeless symbolism.

\title{
References
}

Annensky, I.F. (1906). Mif I tragediia Gerakla [Myth and tragedy of Herakles], In Teatr Evripida [Theater of Euripides]. Saint Petersburg, Prosveshchenie, 413-469.

Golosovker, Ia.I. (1987). Logika mifa [The Logic of the Myth]. Moscow, Nauka, 218 p.

Graves, R. (2005). Mify Drevnei Gretsii [Myths of Ancient Greece]. Ekaterinburg, U-Faktoriia, $1008 \mathrm{p}$.

Hacks, P. (1972). Ausgewählte Dramen. Berlin, Aufbau-Verlag, 451 p.

Kraft, D. Der entkettete Knecht. Philosophische Perspektiven auf Brecht und Hacks und Hegel. Available at: http:/goo.gl/BVes5z (accessed: 10 November 2016).

Mann, T. (1960). «Iosif i ego brat'ia». Doklad [«Joseph and His Brothers». Report], In Mann, T. Sobraniie sochinenii. V desiati tomakh [Mann, T. Collected works. 10 volumes]. Moscow, GIKHL, 172-191.

Schütze, P. (1976). Peter Hacks. A contribution to the aesthetics of drama, antiquity and the appropriation of myth [Peter Hacks. Ein Beitragzur Ästhetikdes Dramas, Antikeund Mythenaneignung]. Kronberg; Taunus, Scriptor Verlag, 303 p.

Sharypina, T.A. (2001). «Ifigeniia v Tavride» Gete na rubezhe XXI veka [«Iphigenia in Tauris» by Goethe at the turn of the $21^{\text {st }}$ century]. In Vestnik Nizhegorodskogo universiteta im. N.I. Lobachevskogo [The bulletin of the Nizhny Novgorod University named after N.I. Lobachevskii]. 1, 116-124.

Tsvetkova, M.V. (2010). Vozmozhnosti retseptivnogo podkhoda v ramkakh komparativistskogo issledovaniia [Possibilities of Reception Approach in the Frame of Comparative Studies]. In Vestnik Viatskogo gos. Gumanitarnogo un-ta [The bulletin of Vyatka State Humanities University]. 2(3), 8-12.

Vengerova, E.V. (1979). Poeticheskii teatr Petera Khaksa [Poetic Theater of Peter Hacks], In Hacks P. P'esy [Hacks, P. Plays]. Moscow, 449-483.

\section{Миф о Геракле}

\section{в художественной интерпретации П. Хакса (на материале произведения «Омфала»)}

\author{
Т.С. Нипа, В.Э. Биктимиров \\ Сибирский федеральный университет \\ Россия, 660041, Красноярск, пр. Свободный, 79
}

В статье рассматриваются особенности художественной рецепиии классического сюжета о Геракле в пьесе П. Хакса «Омфала». Обращение к сюжетам, образам и мотивам древнегреческой мифологии, их интерпретация, авторская мифологизация и мифотворчество есть неотъемлемая часть художественной практики мировой словесности, в частности немеикоязычной литературы. Именно в культуре Германии наиболее мощно сформировалась на- 
цุиональная традиџия художественной интерпретаџии античности. Не исключением стало и творчество Петера Хакса, создавшего ряд оригинальных и самобытных литературных обработок известных мифологических сюжетов («Прекрасная Елена», «Амфитрион», «Орфей в аду»). Анализ пьесы, выполненный в русле рецептивного и компаративного методов исследования, позволяет выявить особенности рецепции античных сюжетов в новейшую эпоху, а также своеобразие мифотворчества немецккого драматурга.

Ключевые слова: П. Хакс, Геракл, Омфала, немецкая литература, рецепџия, миф, интерпретацияя.

Научная специильность: 10.00 .00 - филологические науки. 